\title{
Pelatihan Penulisan Feature Pengalaman Warga Selama Masa Pandemi di Desa Tamantirto, Kasihan, Bantul
}

\author{
Pujiharto, Rakhmat Soleh, Saeful Anwar \\ Fakultas Ilmu Budaya, Universitas Gadjah Mada \\ Korespondensi: pujiharto@ugm.ac.id
}

\begin{abstract}
Tamantirto village, Kasihan, Bantul is an area which is positively responsive in terms of dealing with the Covid-19 pandemic. The citizens' response is not only showed by implementing health protocol and entrances shutdown during the pandemic but is also empowered by the consciousness of knowledge and experience transfer about pandemic for the next generation. Through the existing village's information system, they offer a collaboration to lecturer of Indonesian Language and Letter Study Program of FIB UGM to conduct feature writing training about citizens' point of view and experience during the pandemic. The training is held in two methods. The first is direct training method with power point elaborating the definition, type, example, and writing technique and feature editing. The second one is writing guidance using WA group where the participants can send their work to the group chat and then the trainer give feedback for the document. The training produces 21 feature documents which are averagely elaborate the participants' profession regarding with the pandemic. Most of the documents are written with argumentative paragraph instead of narrating their experience during the pandemic like the common feature which tends to be narrative.
\end{abstract}

Key words: feature; pandemic; Tamantirto; writing workshop

\begin{abstract}
Abstrak
Desa Tamantirto, Kasihan, Bantul merupakan wilayah yang tanggap dalam menghadapi pandemi Covid-19. Ketanggapan warga tidak hanya ditunjukkan melalui penerapan protokol kesehatan dan penutupan sejumlah pintu gang ketika masa pandemi, tetapi juga didukung pada kesadaran akan pentingnya pewarisan pengetahuan dan pengalaman seputar pandemi kepada generasi mendatang. Melalui Tim Sistem Informasi Desa yang mereka miliki, mereka bekerja sama dengan dosen Prodi Bahasa dan Sastra Indonesia FIB UGM untuk mengadakan kegiatan pelatihan penulisan feature seputar pandangan dan pengalaman warga selama pandemi. Pelatihan diselenggarakan dengan dua cara. Pertama, pelatihan secara langsung dengan media power point yang menguraikan definisi, jenis, contoh, dan teknik penulisan serta penyuntingan feature. Kedua, bimbingan penulisan melalui Grup WA ketika peserta mengirimkan karyanya ke grup WA dan narasumber memberikan masukan terhadap naskah tersebut. Pelatihan menghasilkan 21 naskah feature yang rata-rata menguraikan profesi para peserta dan mengaitkannya dengan pandemi. Sebagian besar naskah masih lebih banyak diisi dengan paragraf argumentatif dibandingkan menarasikan pengalaman selama pandemi sebagaimana layaknya feature yang cenderung naratif.
\end{abstract}

Kata kunci: feature; pandemi; pelatihan penulisan; Tamantirto 


\section{Pendahuluan}

Yogyakarta menjadi salah satu wilayah yang cukup tanggap dalam menghadapi pandemi Covid-19. Gagasan karantina mandiri di sejumlah desa dimulai dari Yogyakarta. Sampai kini sejumlah lokasi di Yogyakarta menerapkan standar khusus dalam mengatur keluar masuknya orang ke wilayah mereka. Selain karantina mandiri, beberapa desa juga melakukan penyemprotan ke rumah-rumah warga dengan disinfektan. Langkah-langkah lain juga dilakukan demi mencegah penyebaran virus Covid-19.

Di balik langkah-langkah yang telah diterapkan tersebut, ada diskusi antarwarga serta antara warga dengan perangkat desa yang belum terdokumentasikan. Ada pro dan kontra pada setiap langkah yang kemudian menjadi keputusan bersama. Diperlukan satu kegiatan yang mampu mengungkap dialektika antarwarga sebelum sampai pada pelaksanaan keputusan bersama tersebut. Selain itu, dampak dari diterapkannya langkahlangkah tersebut juga perlu diungkap sebab dengan ditutupnya pintu-pintu masuk desa turut memengaruhi kehidupan sosial dan ekonomi di desa tersebut. Lebih luas lagi, menarik pula untuk mengetahui bagaimana warga menerima informasi seputar virus Covid-19, bagaimana pandangan, reaksi, dan sikap mereka menghadapi pandemi, yang pasti memiliki kekhasan bergantung status sosial-ekonomi dan jenis pekerjaannya.

Kegiatan ini memilih warga Desa Tamantirto, terutama Tim Media Informasi Desa, yang ada di sana untuk menuliskan pengalaman-pengalaman warga dalam bentuk feature selama masa pandemi. Kegiatan ini penting dilakukan agar segala pandangan dan sikap warga dalam menghadapi pandemi dapat didokumentasikan dengan baik yang nantinya dapat menjadi bahan penelitian atau setidak-tidaknya pengetahuan yang dapat diwariskan bagi generasi mendatang.

Untuk diketahui bahwa Desa Tamantirto telah memiliki situs informasi desa yang beralamat tamantirto.bantul.kab.go.id. yang rutin menginformasikan beberapa imbauan dan kebijakan pemerintah kepada warga desa serta memberitakan beberapa agenda dan kegiatan warga. Tim media merasa membutuhkan konten lain berupa feature untuk melengkapi situs tersebut karena feature bersifat lebih santai daripada berita. Selain itu, mereka juga ingin menuliskan kegiatan-kegiatan warga yang sifatnya informal dan nonseremonial sebagaimana selama ini diberitakan. Dalam masa pandemi ini, situs tersebut untuk sementara tidak diaktifkan dan segala informasi disampaikan melalui akun FB Desa Tamantirto. Dengan tidak aktifnya situs berita tersebut, tim media memiliki kesempatan untuk merancang konten baru yang nantinya akan menjadi rubrik sendiri dalam situs tersebut ketika nanti dibuka kembali. Oleh karena itu, Tim Media Desa Tamantirto mengajak kerja sama dengan tim pengabdian untuk mengadakan pelatihan penulisan feature tentang pengalaman warga selama masa pandemi dan pengelolaan rubrik selepas pandemi pada situs informasi desa.

\section{Pendekatan Pelaksanaan Program}

Kegiatan pengabdian kepada masyarakat ini dilaksanakan dengan metode pendampingan kepada masyarakat sasaran. Pendekatan ini dilangsungkan melalui perantara Tim SID Tamantirto yang mejadi perwakilan warga sebelum kegiatan dilangsungkan. Tim SID dan tim PkM melakukan diskusi awalnya melalui ponsel yang dilanjutkan dalam beberapa kali pertemuan untuk membahas (1) jenis tulisan apa yang akan diberikan 
kepada para peserta $\mathrm{PkM}$, (2) tema tulisan yang akan dihasilkan para peserta, dan (3) bagaimana metode $\mathrm{PkM}$ dilangsungkan.

Jenis tulisan yang akan dijadikan materi pelatihan awalnya adalah cerpen, tetapi kemudian hasil diskusi akhirnya menghasilkan keputusan adanya pelatihan penulisan feature. Feature dianggap lebih mudah untuk diaplikasikan mengingat sebagian besar peserta adalah mereka yang ingin belajar menulis. Dalam feature, mereka dapat menuliskan apa yang mereka alami dan apa yang mereka pikirkan secara apa adanya, sedangkan dalam cerpen mereka harus memanipulasi pengalaman dan meminimalisasikan hasil pemikiran mereka demi cerita yang menarik dengan bertumpu pada imajinasi. Adapun tema yang kemudian dipilih adalah pandangan dan pengalaman seputar pandemi Covid-19 untuk memudahkan peserta menulis feature sebab apa yang dialami lebih mudah untuk dituliskan daripada yang tidak dialami.

Pelaksanaan pelatihan akhirnya diputuskan diadakan dengan menempuh dua metode, yakni penyampaian materi secara langsung dan pembimbingan secara daring melalui grup WA. Hal itu diputuskan dengan beberapa pertimbangan. Pertama, para peserta tidak semuanya memiliki perangkat yang memadai untuk ikut secara daring dan tidak pula memiliki akses internet yang cukup kuat. Kedua, apabila masyarakat dikumpulkan ke balai desa untuk mengikuti pelatihan secara daring, narasumber juga turut serta dihadirkan. Ketiga, penyampaian materi secara langsung dianggap lebih efektif daripada dilakukan secara daring. Keempat, para peserta meraswa diuwongke 'dimanusiakan' - merasa dihargai-apabila narasumber menemui mereka secara langsung yang juga akan berdampak pada meningkatkanya motivasi peserta dalam mengikuti pelatihan.

\section{Pelaksanaan Program}

Kegiatan dilaksanakan pada 18 Juli 2020 di Balai Desa Tamantirto, Kasihan, Bantul. Kegiatan ini diikuti oleh 30 peserta yang terdiri atas beragam latar belakang, yakni mulai dari siswa sekolah, mahasiswa, seniman, ibu rumah tangga, anggota polisi, tenaga kesehatan, dan lain sebagainya. Sebagaimana kegiatan formal lainnya, kegiatan dibuka dengan sejumlah sambutan dari perwakilan pemerintah desa dan perwakilan tim PkM untuk mengenalkan narasumber dan tujuan diadakannya kegiatan.

Penyampaian materi yang pertama diuraikan oleh Dr. Pujiharto, M.Hum. mengenai definisi feature. Dalam uraiannya disebutkan bahwa feature merupakan karangan khas yang bukan berupa laporan berita sehingga tidak memiliki tata penulisan laporan berita yang mengutamakan peristiwa dengan prinsip $5 \mathrm{~W}+1 \mathrm{H}$. Feature merupakan karya kreatif yang terkadang bersifat subjektif, yang dirancang untuk menginformasikan sekaligus menghibur pembaca tentang berbagai aspek kehidupan, yang dapat terkait dengan mata pencaharian, tren suatu masa, perkembangan ilmu pengetahuan dan teknologi, dunia wisata, dan lain sebagainya.

Menurut Bleyer (2016:9-10), feature merupakan tulisan yang menyajikan fakta dalam bentuk yang menarik dan ringkas untuk menghibur atau menginformasikan sesuatu kepada khalayak yang berkaitan dengan 3 hal, yakni (1) berita terkini yang memerlukan penjelasan, (2) topik yang aktual atau musiman yang tidak berhubungan langsung dengan berita, dan (3) hal umum yang tidak memiliki hubungan langsung 


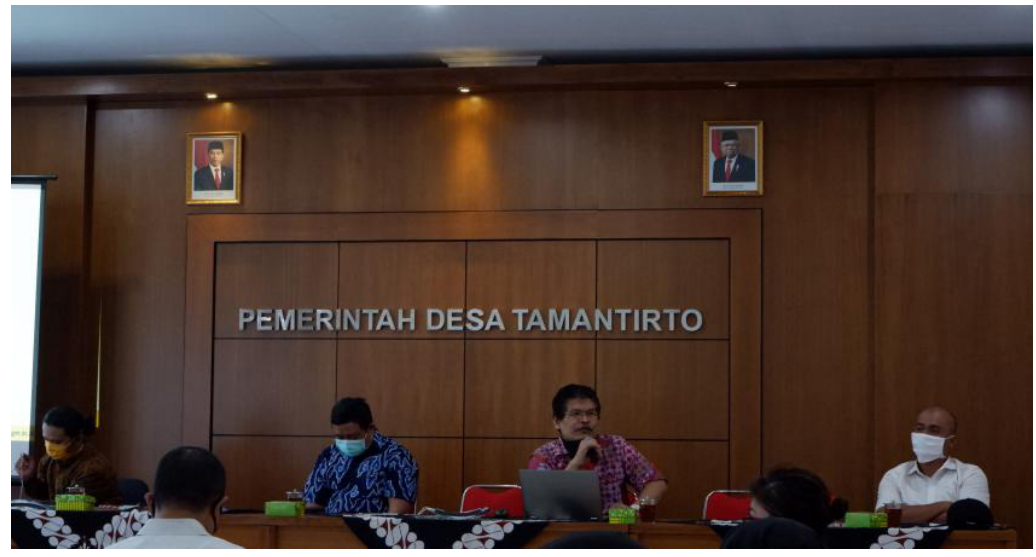

Gambar 1. Dr.

Pujiharto, M.Hum. sedang memaparkan definisi dan ciri feature. (Sumber: Dokumentasi Pribadi)

dengan peristiwa terkini. Jika berita ditulis untuk membawa informasi yang penting diketahui pembaca, fungsi feature adalah melengkapi informasi tersebut dengan menghadirkan tulisan yang menghibur. Unsur hiburan ini berkisar tentang segala yang berkaitan dengan kehidupan manusia. Adapun cara penulisannya mirip seperti karya sastra dengan gaya tuturan, yang berisi campuran antara deskripsi dan narasi dengan sedikit argumentasi. Dengan kecenderungan cara penulisan semacam itu, feature memiliki alur penceritaan yang akan membuat pembaca seakan-akan ikut mengalami peristiwa yang dituliskan.

Feature merupakan tulisan berdasarkan data dan fakta peristiwa aktual, tetapi materinya diseleksi dengan lebih menekankan pada sisi human interest (Rahardi, 2006:30). Meskipun demikian, aktualitas di dalam feature tidak terlalu ditekankan sebagaimana yang dibebankan kepada berita. Dengan demikian, apa yang ditawarkan kepada pembaca adalah hal-hal unik yang selama ini luput dari pemberitaan sehingga dibutuhkan cara berpikir yang out of the box untuk menentukan topik yang akan ditulis dalam sebuah feature.

Umumnya, feature ditulis dalam jumlah kata yang cukup sedikit, yakni antara 750-1.000 kata. Contoh feature yang bagus dapat dibaca dalam sejumlah majalah, seperti Tempo dan National Geografi serta surat kabar seperti Kompas, Media Indonesia,

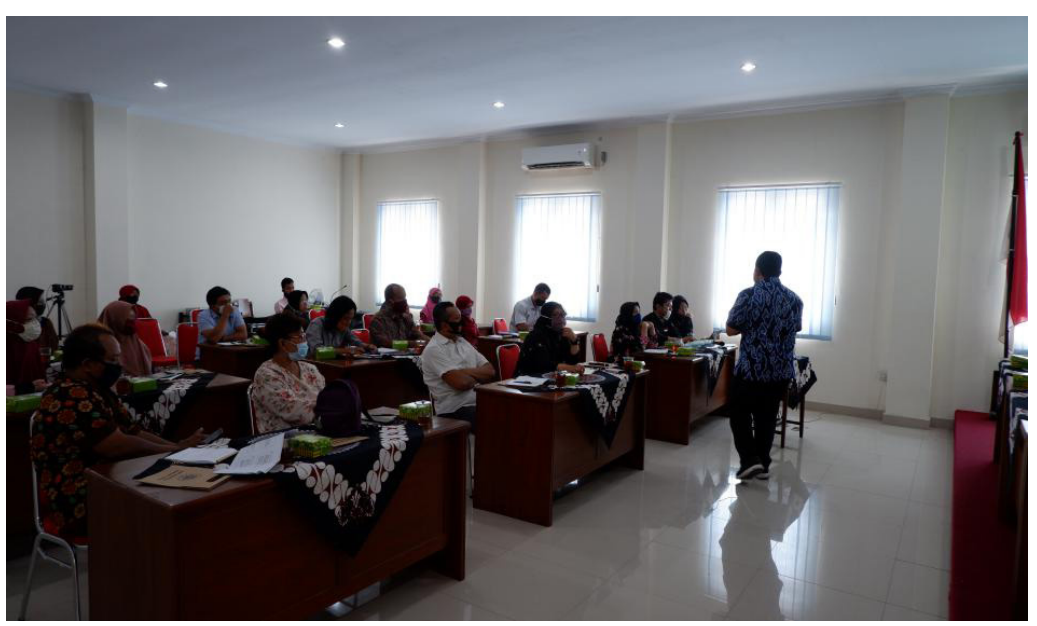

Gambar 2. Rakhmat Soleh, S.S., M.Hum. sedang menguraikan jenis-jenis feature berikut contohnya. (Sumber: Dokumentasi pribadi) 
Kedaulatan Rakyat, dan lain-lain. Adapun di dalam situs berita dapat ditemukan di tirto.id, kumparan.com, cnnindonesia.com, dan lain-lain.

Setelah penjelasan seputar definisi dan ciri feature, penyampaian materi dilanjutkan dengan uraian mengenai jenis-jenis feature yang disampaikan oleh Rakhmat Soleh, S.S., M.Hum.

\section{Human interest}

Feature ini ditulis dengan tujuan untuk langsung menyentuh perasaan pembaca, dapat berupa keharuan, kegembiraan, kejengkelan, dan simpati pembaca. Tujuan tersebut menyebabkan feature jenis ini kerap kali mengangkat hal-hal yang menjadi common sense. Sensitivitas menjadi dasar dalam penyusunannya. Misalnya, feature tentang pekerjaan seorang penggali kubur, serba-serbi seputar kebutuhan panggung seorang biduan dangdut, nasib guru di pesantren selama pandemi Covid-19, dan lain-lain.

\section{Perjalanan}

Feature ini berupa catatan perjalanan yang mengurai pengalaman selama perjalanan dalam hubungannya dengan ruang, waktu, dan objek. Feature perjalanan yang banyak terdapat dalam media massa lebih banyak menghadirkan keindahan objek wisata daripada gambaran pengalaman perjalanan yang telah dilakukan. Contoh: pengalaman berwisata ke Pantai Parangtritis, pengalaman mengunjungi museum, dan lain-lain.

\section{Biografi/Profil}

Feature yang mengisahkan riwayat hidup seseorang. Biasanya orang yang dikisahkan memiliki banyak prestasi dan jasa kepada masyarakat. Selama ini, biografi/profil lebih banyak berisi tentang publik figur seperti selebritas dan pejabat. Padahal, sejatinya dalam biografi bisa juga dituliskan tentang orang-orang yang selama ini memiliki banyak jasa tetapi jarang dituliskan, seperti profil penyapu jalanan kota, profil kuncen sebuah makam, pedagang kaki lima dengan banyak pelanggan, dan lain sebagainya, guna melengkapi profil-profil orang besar yang sudah dituliskan seperti kisah tentang Hamengku Buwono IX, Jenderal Sudirman, dan lain-lain.

\section{Sejarah}

Feature yang membahas peristiwa pada masa lalu dengan tafsir baru yang dikaitkan dengan kondisi kekinian. Dalam penulisannya dibutuhkan teknik kontekstulisasi dengan cara menghadirkan cara pandang sekarang terhadap masa lalu agar pembaca tertarik untuk membacanya. Sejarah yang dituliskan juga tidak harus melulu seputar peristiwa politik, tetapi bisa juga berkaitan dengan peristiwa budaya. Contoh: sejarah dibunyikannya terompet dekat Pasar Beringharjo tiap 1 Maret, sejarah Masjid Agung dan kaitannya dengan perjuangan kemerdekaan, sejarah penyelenggaraan pasar sekaten, dan lain-lain.

\section{Ilmiah}

Feature yang menyajikan temuan terbaru di sejumlah bidang ilmu pengetahuan. Contoh: teknologi 5G, mobil listrik, google glass, dan lain-lain.

\section{Tren}

Feature yang membahas hal yang sedang tren pada masa sekarang. Contoh: fenomena orang bersepeda pada masa kini, tren webinar atau kelas daring pada masa pandemi, dan lain-lain. 


\section{Musiman}

Feature yang membahas masalah yang rutin berlangsung tiap waktu dalam rentang waktu tahunan. Musim durian, ngabuburit di bulan puasa, musim layang-layang, dan lain-lain.

\section{How-to}

Feature yang menjelaskan tata cara penggunaan alat atau teknologi baru dengan cara menceritakan bagaimana proses penggunaan sebuat alat tersebut berikut kesan terhadap pengalaman penggunaan tersebut. Contoh: pengalaman menggunakan aplikasi Zoom untuk rapat dan lain-lain.

Dalam menguraikan jenis-jenis feature tersebut, narasumber juga menunjukkan sejumlah contohnya. Banyaknya jenis feature menunjukkan bahwa banyak permasalahan manusia yang dapat ditulis menjadi feature, tetapi yang perlu ditekankan adalah bagaimana manusia mengalami dan menghadapi masalah itu. Permasalahan lebih cocok ditulis dalam esai, sedangkan feature menekankan pada sisi kemanusiaannya (Rahardi, 2006:31).

Setelah penjelasan mengenai jenis-jenis feature dan contohnya, uraian berlanjut tentang teknik penulisannya yang disampaikan oleh Saeful Anwar, S.S., M.A. Valerie (2014:7) mengatakan bahwa tempat ide ditemukan dan cara mendapatkan ide tersebut penting untuk kesuksesan seorang penulis karena tanpa ide-ide yang baru dan menarik akan sulit menarik perhatian pembaca. Oleh karena itu, narasumber menjelaskan cara dan sumber ide dapat ditemukan.

Dalam How To Write a Feature Article: Your Step-By-Step Guide To Writing Feature Articles (2011: 18-23) dijelaskan bahwa ada banyak sumber penulisan feature, misalnya berita atau kejadian aktual, artikel dalam majalah, pengalaman, pengamatan, karya ilmiah, iklan, televisi dan radio, pameran seni, buku, ceramah, perjalanan, dan lain sebagainya. Namun, narasumber menekankan agar para peserta mengambil ide penulisan dari pengalaman hidupnya yang didapatkan dari lingkungan sekitarnya dan mengarahkan pada pengalaman para peserta selama masa pandemi. Hal ini dilakukan agar pembaca tinggal merefleksikan apa yang sudah mereka alami tanpa harus mencari dari sumber penulisan lainnya yang bisa jadi akan memakan waktu lebih lama. Hasil

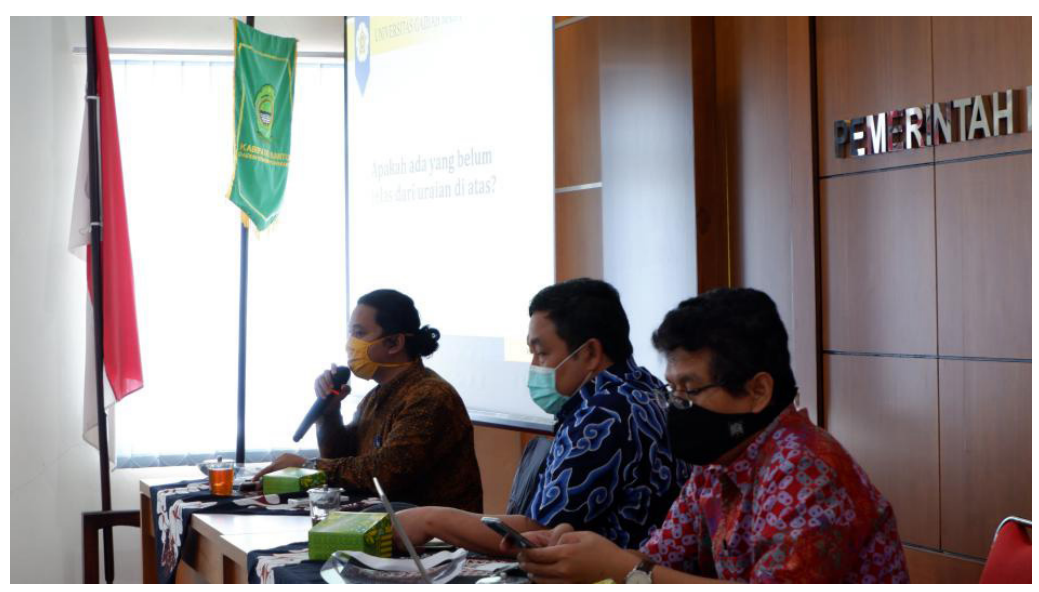

Gambar 3. Saeful Anwar, S.S., M.A. sedang menguraikan teknik penulisan feature. (Sumber: Dokumentasi pribadi) 
refleksi terhadap pengalaman tersebut nantinya dinarasikan dengan mengungkapkan kesan-kesan dan harapan ke depan mengenai hal yang dituliskan.

Refleksi pengalaman pribadi tersebut akan lebih mantap dijadikan sebagai bahan tulisan ketika didukung oleh hasil obrolan dengan orang lain dan membaca sejumlah literatur mengenai topik yang sedang dituliskan, baik berupa buku, majalah, tabloid, koran, maupun situs internet. Disarankan oleh narasumber agar peserta juga membaca sejumlah feature yang ada di media massa sebagaimana telah disinggung oleh narasumber sebelumnya. Dengan membaca sejumlah feature akan didapatkan dua manfaat. Pertama, secara tidak langsung mempelajari cara menulis feature yang baik melalui contoh nyata. Kedua, mempelajari kecenderungan feature semacam apa yang biasa dimuat di media massa agar nanti ada penyesuaian ketika menulis.

Secara garis besar, narasumber menjelaskan bahwa ada tujuh langkah untuk menulis feature, yakni (1) menentukan topik tulisan sesuai minat, (2) memberikan alasan mengapa topik itu penting ditulis, (3) menentukan tujuan penulisan, (4) membuat kerangka karangan, (5) mengumpulkan data sesuai dengan kebutuhan kerangka karangan yang telah disusun, (6) memasukkan data dalam proses penulisan sesuai kerangka karangan yang sudah disusun, dan (7) merevisi ketika tulisan sudah jadi dengan cara membaca ulang dengan memperhatikan ejaan, penyusunan kalimat, paragraf, serta substansi tulisan. Narasumber juga menjelaskan bahwa saat membuka feature harus membuat paragraf yang mampu memikat pembaca agar mereka penasaran dengan isi feature sehingga akan menyelesaikan pembacaan mereka. Mengutip Sumner dan Miller (2009:105), narasumber menjelaskan bahwa setidaknya dalam membuka tulisan harus memuat empat hal, yakni menarik perhatian pembaca, mengenalkan topik, membangun suasana, dan menempatkan sudut pandang.

Setelah semua narasumber menguraikan materinya, acara dilanjutkan dengan sesi tanya jawab. Para peserta sangat antusias dengan kegiatan ini. Hal ini dapat dilihat dari pertanyaan-pertanyaan yang diajukan. Secara garis besar, berikut pertanyaan dari peserta dan jawaban yang diberikan oleh narasumber.

1) Sebaiknya feature ditulis dalam berapa kata?

Narasumber menjelaskan bahwa hal tersebut sudah diuraikan pada awal pemaparan materi. Jumlah kata dalam sebuah feature adalah antara 750-1.000 kata. Tentu, penulisan ini harus menyesuaikan media massa yang akan disasar untuk publikasi hasil tulisan kita. Apakah media terkait memiliki ruang yang luas atau tidak untuk memuat feature yang akan menentukan jumlah kata.

2) Bagaimana cara mengembangkan ide penulisan feature?

Narasumber menjelaskan bahwa pengembangan ide dapat dilakukan dengan cara membaca sejumlah literatur yang berkaitan dengan ide yang telah ada. Ide itu juga dapat dikembangkan dengan cara mencari informasi kepada sejumlah narasumber yang nanti data wawancaranya secara tidak langsung akan mengembangkan ide yang sudah ada.

3) Untuk menulis feature berlatar sejarah, apakah dibutuhkan riset?

Narasumber menguraikan bahwa setiap tulisan yang baik membutuhkan riset, tetapi riset dalam pengertian ini bukanlah riset akademis. Riset dalam proses penulisan adalah pencarian informasi sebanyak mungkin untuk dapat menyimpulkan gagasan yang logis dan mencari celah apa yang selama ini belum dituliskan. Termasuk 
dalam soal sejarah, riset dibutuhkan untuk tahu bahwa apa yang nanti dituliskan adalah sesuatu yang baru, tidak mengulang, atau mereproduksi informasi sejarah yang sudah pernah dituliskan sebelumnya.

4) Apa tip dan trik agar tulisan diterima di media massa?

Narasumber memberikan tip dan trik agar tulisan bisa dimuat di media massa dengan cara mempelajari apa yang sering dimuat di dalam media terkait, dari segi tema yang sering diangkat dalam media tersebut sampai bagaimana gaya tulisan yang ada di sana. Setiap kali tulisan dikirim ke media tetapi dalam waktu satu bulan tidak dimuat, tulisan dapat ditarik untuk dikirimkan ke media lainnya. Rutin dan konsistensi dalam mengirim tulisan ke media dapat menjadi salah satu daya tawar selain substansi dari tulisan yang kita miliki.

5) Ketika feature dibaca orang lalu ada yang tersinggung, bagaimana sikap kita? Bagaimana menulis feature yang harus menyinggung seseorang, tapi tidak sampai melanggar UU ITE?

Narasumber berpendapat bahwa sebaiknya kita memberikan sikap yang wajar ketika menghadapi orang yang tersinggung dengan tulisan kita. Sikap wajar itu dapat dilakukan dengan meminta maaf dan melakukan klarifikasi jika memang kita melakukan kesalahan. Namun, apabila terjadi perbedaan argumen, orang yang tersinggung diminta untuk menulis karya tandingan. Hal ini jarang terjadi dalam penulisan feature sebab lebih banyak narasi yang apa adanya dibandingkan argumentasi dengan sejumlah alasan. Jadi, akan sulit terjadi ada feature yang melanggar UU ITE, adapun jika ingin menghindarinya cukup tidak perlu menyebutkan nama seseorang atau instansi tertentu apabila hendak menulis sesuatu yang bersifat sensitif.

6) Bagaimana untuk meningkatkan daya baca, sebab menurut narasumber, salah satu hal yang mendukung penulisan adalah minat baca yang besar?

Narasumber menyarankan bahwa untuk meningkatkan daya baca dapat ditempuh dengan membaca buku atau bahan bacaan lainnya yang berisi tentang sesuatu yang menjadi minat, atau sesuatu yang disukai, yang nanti perlahan-lahan akan menumbuhkan minat pada hal-hal lain, dan tentu bacaan-bacaan lainnya.

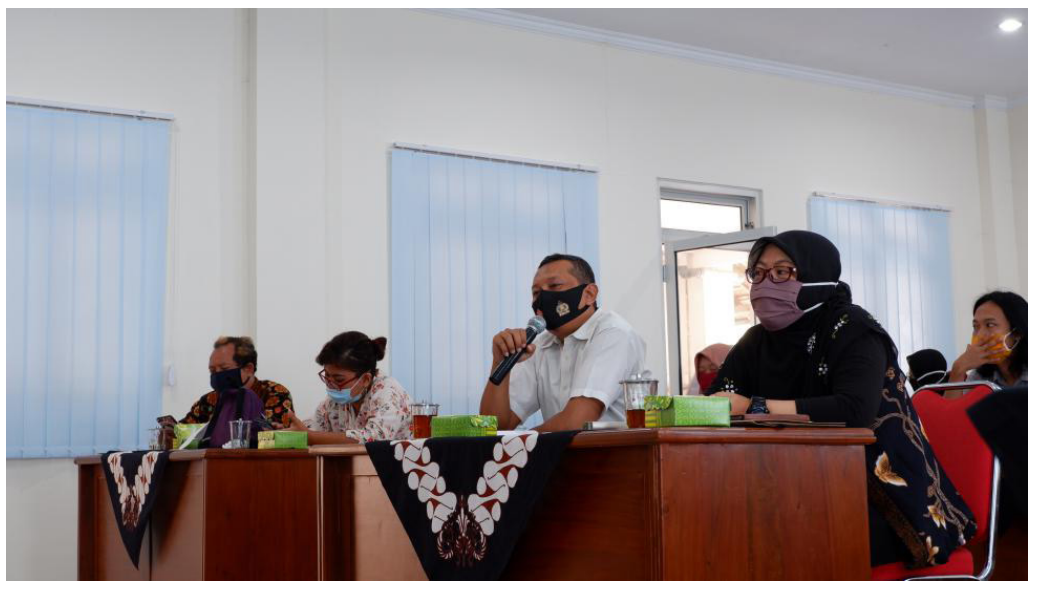

Gambar 4. Salah satu peserta pelatihan mengajukan pertanyaan kepada narasumber. (Sumber: Dokumentasi Pribadi) 
Setelah kegiatan tersebut, melalui bantuan tim SID (Sistem Informasi Desa) para peserta dibagi ke dalam 3 grup WA untuk dibimbing dalam penulisan feature. Dalam grup itu juga sudah ada jadwal diskusi berikut urutan waktu penulisan dan rencana penerbitan karya para peserta. Namun, peserta tidak begitu aktif di dalam grup tersebut meskipun narasumber aktif menyapa dan mengingatkan penulisan feature mereka. Pada akhirnya, mereka menjadi aktif ketika yang menghubungi adalah Tim SID Tamantirto sehingga proses menulis mereka diperantarai oleh tim tersebut. Total ada 21 tulisan yang dihasilkan oleh para peserta yang kemudian diterbitkan dalam sebuah bunga rampai berjudul Kami Melawan Pandemi: Pandangan dan Pengalaman Warga Tamantirto terhadap Pandemi Covid-19.

\section{Refleksi Capaian Program}

Berdasarkan kegiatan $\mathrm{PkM}$ yang telah dilaksanakan, ada sejumlah kendala yang dihadapi, yang kemudian menjadi kekurangan dari kegiatan ini. Pertama, para peserta yang mengikuti program, yang semula membersitkan harapan akan keragaman tulisan berdasarkan latar belakang mereka, ternyata merasa terbebani untuk menulis. Hal ini diindikasikan dari tidak aktifnya mereka pada grup WA untuk bimbingan menulis dan pada akhirnya tulisan terkumpul ketika ditagih oleh Tim SID Tamantirto dalam waktu yang cukup lama. Hal ini menjadi catatan bagi tim pengabdian bahwa untuk mengadakan pelatihan penulisan, apa pun jenisnya, harus menyasar pada masyarakat yang memang membutuhkannya. Misalnya, untuk penulisan feature masyarakat sasarannya adalah calon-calon jurnalis, untuk penulisan cerpen masyarakat sasarannya adalah anggota komunitas menulis, dan seterusnya. Kendala pertama ini akhirnya bisa diatasi berkat bantuan tim SID Tamantirto yang turut memotivasi para peserta agar menyelesaikan kewajiban menulisnya.

Kedua, pelatihan penulisan sebaiknya dipraktikkan dan dibimbing langsung. Cara ini akan lebih efektif dibandingkan melalui grup WA atau perangkat daring lainnya. Hal ini dapat dilihat dari pengabdian-pengabdian sebelumnya yang dilaksanakan secara langsung tidak mengalami kendala yang cukup berat terkait bagaimana keaktifan peserta.

Ketiga, terkait dengan hasil tulisan peserta, ada dua hal yang tidak sesuai dengan pelatihan, yaitu terkait topik tulisan dan teknik penulisan. Ada sejumlah tulisan yang tidak mengangkat tentang pandemi Covid-19, tetapi tentang kehidupan mereka yang tidak berkaitan dengan pandemi. Sementara itu, dari teknik penulisan masih ada sejumlah naskah yang lebih terasa sebagai esai daripada feature. Ternyata, para peserta lebih suka mengungkapkan argumennya di dalam tulisan daripada sekadar menarasaikan pengalamannya mengenai pandemi.

Manfaat adanya kegiatan ini dirasakan langsung oleh tim SID Tamantirto yang juga menjadi peserta. Mereka mulai menyadari bahwa ada banyak objek di desa tersebut yang dapat ditulis dalam feature. Misalnya, tentang asal-usul sebuah sendang yang ada di sana, bagaimana Tamantirto banyak dihuni oleh para seniman, kisah Bregodo Tirto Yudho yang diakui keberadaannya oleh Keraton Yogyakarta, dan lain sebagainya. Mereka berharap bahwa ke depannya bisa menjalin kerja sama lagi bersama tim $\mathrm{PkM}$ dengan peserta yang terbatas, yakni khusus tim SID Tamantirto dan berharap mendapatkan 
pelatihan penulisan dari langkah ke langkah, tidak sebagaimana yang dilakukan saat diadakan kegiatan ini yang masih banyak penjelasan secara umum.

\section{Penutup}

Kegiatan pelatihan penulisan feature di Desa Tamantirto, Kasihan, Bantul, secara garis besar telah menghasilkan 21 feature karya para peserta yang telah dibukukan. Sebagian besar naskah masih lebih banyak diisi dengan paragraf argumentatif daripada menarasikan pengalaman selama pandemi sebagaimana layaknya feature yang cenderung naratif. Kegiatan ini juga telah menumbuhkan kesadaran tim SID Tamantirto untuk menulis feature mengenai desanya. Kesadaran ini perlu terus dibina untuk diwujudkan sehingga akan ada banyak feature tentang Desa Tamantirto yang bisa dijadikan sebagai media pembelajaran bagi warganya. Oleh karena itu, pada periode berikutnya akan diadakan pembimbingan kepada tim SID Tamantirto untuk menulis feature dan mengelola rubrik feature sebagaimana rencana sebelumnya yang belum terwujud.

\section{Daftar Pustaka}

Bleyer, W. G. (2016). How to Write Special Feature Articles. Anboco.

Hockert, V. (2014). Teaching Feature Writing an Eight Week Lesson Plan, Smashwords Edition. Justice Gray.

How Expert. (2011). How To Write a Feature Article: Your Step-By-Step Guide To Writing Feature Articles. HowExpert.com. https://www.howexpert.com.

Rahardi, F. (2006). Panduan Lengkap Menulis Artikel, Feature, dan Esai. Depok: Kawan Pustaka.

Sumner, D. E. dan Holly G. M. (2009). Feature and Magazine Writing. UK: Wiley \& Blackwell Ltd. 